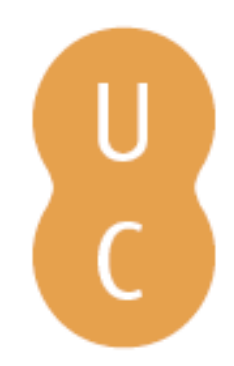

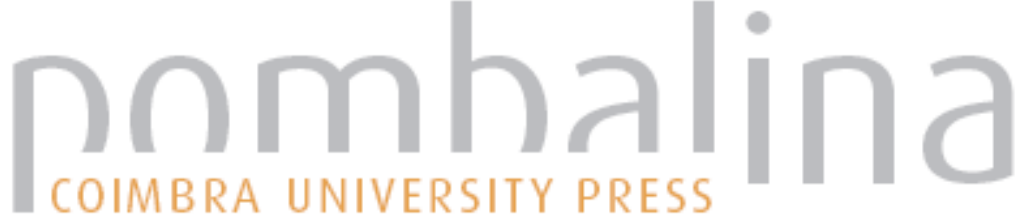

\section{The philosophy of nature of German idealism}

\author{
Autor(es): $\quad$ Morujão, Carlos
}

Publicado por: Imprensa da Universidade de Coimbra

URL

persistente: URI:http://hdl.handle.net/10316.2/31649

DOI: $\quad$ DOI:http://dx.doi.org/10.14195/978-989-26-0205-9_14

Accessed : $\quad$ 26-Apr-2023 11:20:34

A navegação consulta e descarregamento dos títulos inseridos nas Bibliotecas Digitais UC Digitalis, UC Pombalina e UC Impactum, pressupõem a aceitação plena e sem reservas dos Termos e Condições de Uso destas Bibliotecas Digitais, disponíveis em https://digitalis.uc.pt/pt-pt/termos.

Conforme exposto nos referidos Termos e Condições de Uso, o descarregamento de títulos de acesso restrito requer uma licença válida de autorização devendo o utilizador aceder ao(s) documento(s) a partir de um endereço de IP da instituição detentora da supramencionada licença.

Ao utilizador é apenas permitido o descarregamento para uso pessoal, pelo que o emprego do(s) título(s) descarregado(s) para outro fim, designadamente comercial, carece de autorização do respetivo autor ou editor da obra.

Na medida em que todas as obras da UC Digitalis se encontram protegidas pelo Código do Direito de Autor e Direitos Conexos e demais legislação aplicável, toda a cópia, parcial ou total, deste documento, nos casos em que é legalmente admitida, deverá conter ou fazer-se acompanhar por este aviso.

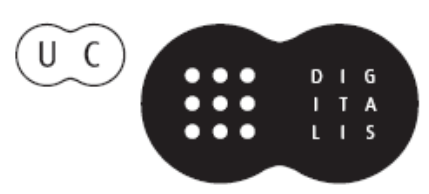


Edmundo Balsemão Pires

Burkhard Nonnenmacher

Stefan Büttner-von Stülpnagel

Editors

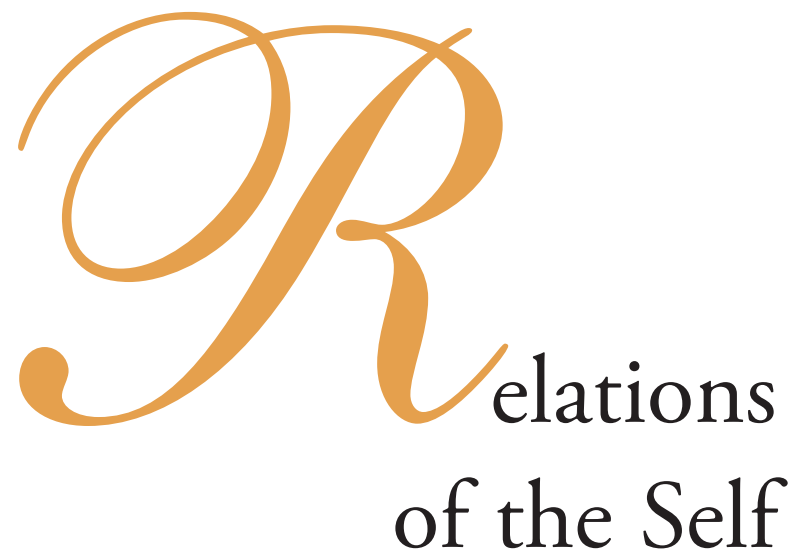




\section{Carlos Morujāo \\ Universidade Catolica Portuguesa}

\section{THE PHILOSOPHY OF NATURE OF GERMAN IDEALISM ${ }^{1}$}

At first sight it seems not only possible but also legitimate to connect the philosophy of nature of German idealism, particularly Schelling's philosophy of nature, with certain modern theories developed in the course of debates about self-organization and auto-poiesis, or, in another domain, about the evolution of the universe. That such relations are conceivable is testified by the several essays made: more than three decades ago, the northAmerican philosopher Joseph Esposito related Schelling's philosophy of nature with the "general system theory», formulated for the first time before the Second World War by Ludwig von Bertalanffy ${ }^{2}$. In the same order of ideas we could also mention, in Germany, the work, a little more recent, of Wolfdietrich Schmied-Kowarzik ${ }^{3}$. Our observations in this paper will follow almost along the same line. Nevertheless, we should not forget a specificity of German idealism that must be ketp in mind. The philosophy of nature, in the case of Schelling as in the case of Hegel, may well take its point of departure in the achievements of contemporary science, with the aim of joining them together in a convincing narrative of the phases of the evolution of natural processes; that's what happened in relation to Blumenberg's Bildungstrieb, in the case of Schelling, or to the theory of analytical functions of Lagrange, in the case of Hegel, to mention only two exemples choosen almost at random. But as long as the transcendental motive is still present in both, Schelling and Hegel, such a philosophy of nature tries to understand philosophically the conditions of possibility of the natural processes themselves. And since the real issue are the natural processes - and not only, as it was the case with Kant, our knowledge about them - philosophy assumes the task of showing how they are possible, at the same time, as natural phenomena and as objects of a conscience that thinks them ${ }^{4}$. Besides, Schelling and Hegel have a peculiar and somewhat

${ }^{1}$ Along this paper, references to Schelling are from the Sämmtliche Werke (SW), Stuttgart und Augsburg, J. G. Cotta, 1856-1861, and the Historisch-Kritische Ausgabe (HKA), Stuttgart-Bad Cannstatt, Frommann-Holzboog, 1975 and ff. References to Hegel's Encyclopaedia are from the Sämtliche Werke (herausgegeben von Hermann Glockner), repr. Stuttgart-Bad Cannstatt, Frommann-Holzboog, 1965.

${ }^{2}$ Joseph Esposito, Schelling's Idealism and Philosophy of Nature, Lewisburg / London, Bucknell University Press / Associated University Press, 1977, pp. 98 and ff.

3 Wolfdietrich Schmidt-Kowarzik, "Von der wirklichen, von der seyenden Natur», Stuttgart-Bad Cannstatt, Frommann-Holzboog, 1996

${ }^{4}$ Idem, Ibidem, p. 168. 
strange manner of considering the origine of some scientific concepts such as cause, force or law. Sometimes they don't appear to have for both of them any precise mathematical meaning, but only to have been engendered at some stage or other of the evolution of nature, such as the respective philosophical systems have reconstructed it.

Anyway, even if I am right, I think there is still much to learn in this idealistic conception of natural phenomena. One of the central ideas of the philosophy of nature of German idealism is that the world is a unity that sustains itself, does not require any outer foundation to explain its movements and the relation between its parts, and that the observer is engendered by the very same process that engenders the totality of phenomena he observes and each of them in particular. We can see it easily, for instance, in the way Schelling or Hegel deal with the concept of force, refusing to take force as a quasi-hidden agency and presenting it as something that manifests itself when the natural philosopher tries do describe the systematic articulations of the empirical results of science. In the case of Hegel, it has been already noted that on occasion he has an almost phenomenological notion of force, in the sense of Ernst Mach, and not a substantive one ${ }^{5}$. We will see all this, to beginn with, in the analysis of the various theories about the existence of the material world; next, by an analysis of the concepts of life and self-organization. At last, we will see if some modifications in the above mentioned assumptions won't be necessary when we move from the natural world to the world of spirit and freedom.

\section{The Material World}

Concerning the problem of the existence of a material world as well as the problem that the investigation of the mode of being of this material world poses to the philosopher, Schelling says in his Ideas towards a Philosophy of Nature of 1797 they are both the outcome of an artificial separation between man and nature. Together they testify the fact that consciousness is outside the absolute (that does not know any separation) and, as Schelling puts it in 1796, in the Philosophical Letters on Dogmatism and Criticism, poses something opposed to it. This assumption, as is well known, underlies the interpretation Schelling offers of the origin of the famous Kantian question «how are a priori judgments possible?» ${ }^{6}$ Attempting to explain the a priori synthesis, Kant was trying in vain to reunite intuition and concept, opposed by the above mentioned separation.

From the standpoint of the transcendental philosopher, in the Critic of Pure Reason, Schelling also argued, the philosophical consciousness could only be a kind of observer situated outside the system of the world, unable of plainly rendering account of his own origin and of his knowledge about this same world ${ }^{7}$, condemned to give only a canon of all its possible interpretations (whether idealistic, realistic, skeptical, or other). Kant's first Critic is the only

\footnotetext{
${ }^{5}$ Cf. Gerd Buchdahl, "Hegel's philosophy of nature and the structure of science», in Robert Stern (ed.), Hegel, Critical Assessments, London and New York, Rontledge, 1993, vol. IV, p.18

${ }^{6}$ Cf. SW, I, p. 194 / HKA, I/3, p. 60.

${ }^{7}$ Joseph Esposito, Schelling's Idealism and Philosophy of Nature, p. 98.
} 
work of its kind in the history of philosophy, as Schelling emphasizes, because it has no point of view of its own, since it legitimates them all $^{8}$. In this perspective, the kantian book of 1781 would even have failed its main purpose, since it showed itself unable of offering a convincing refutation of dogmatism as the only alleged legitimate point of view; the Critic has only refuted what Schelling labels «dogmaticism», that is, an attitude towards knowledge that refuses to submit it to a previous investigation about its scope and limits. But Kant did not refute the real dogmatism that separates man and the outer world and opposes the latter to the former. In face of this situation, as we shall see later, a monism of the spinozistic kind will appear to Schelling as an acceptable alternative.

1. Kant doesn't approach directly the problem of the reality of the exterior world from an epistemological point of view; in the first Critic, he only defends the formal completeness of a categorial set of principles that would guarantee the possibility of the foundation of a metaphysics of nature. As to the universal validity of the Newtonian gravitational theory Kant is a little more cautious; in the $\$ 38$ of the Prolegomena to any Future Metaphysics he says that the coherence of the diferent components of the theory stongly support the hypothesis of its validity. But the central point, for Kant, is wether in the field of natural sciences we can talk of apodictic principles, as is the case with physics, or only from laws taken from experience, as in the case with chemistry or psychology ${ }^{9}$. About the kantian pretension of giving a metaphysical justification of those principles we will speak later.

2. Schelling in his Ideas, written in the year that followed the publication of the above mentioned Philosophical Letters, emphasizes the artificial character of the separation between consciousness and the outer world. That separation became only possible by reflection, and Schelling even thought it justified - after the immediate relation to nature was lost for humanity - by cognitive interests, so that at least a foundation could be given to the whole field of our scientific experience; but that separation should not be systematically kept, since the essence of man, the basis of his healthy relation with himself and with nature, is based not in reflection but in action ${ }^{10}$. Thus, for Schelling, if the separation from nature, that rendered possible the satisfaction of those interests, was an effect of human freedom, the reestablishment of unity should also be the consequence of freedom. The proclaimed impossibility of reestablishing the unity manifests only the predominance of a mechanistic way of thinking.

3. Hegel strongly criticizes Schelling's position in the Second Part of The Encyclopedia of Philosophical Sciences. Hegel remarks in the Addendum to $\$ 246$ that in order to know nature we must, on one side, capture it just in the way gives itself to us and, on the other, attribute to natural phenomena the determination of universality. But, the more there is of universality in our thought about things, the more they have lost their natural character and singularity. That's why the theoretical attitude contains in itself a contradiction, as long as it

\footnotetext{
${ }^{8}$ Cfr. SW, I, p. 177 / HKA, I/3, p. 68.

${ }^{9}$ Kant, Metaphysiche Anfangsgründe, Vorrede, A V. Cf. Joseph Esposito, Ibidem, pp. 49-50. Esposito describes this situation, as viewed by Kant, with the following words: «His [sc. the chemist] knowledge of the physical events remained on the sensory level and never contained a priori laws that governed the processes of chemical interaction. It was futile for him to classify the compounds into salts, earthes or calces, as had been done extensively prior to the end of the eighteenth century, and still hope to achieve a universal scientific knowledge in this fashion.» (op. cit., p. 50)

${ }^{10}$ SW, II, p. 13 / HKA, I/5, p. 71.
} 
seems to do what goes against its proclaimed goal. But we can't go beyond the opposition between objective and subjective by simply proclaiming the existence of a state of innocence, where man had not yet abandoned nature and would be acquainted with it as from inside.

4. In this constellation of authors, Fichte occupies a special place. As he himself will write to Schelling, in a letter dated from the 15 th of November $1800^{11}$, for the transcendental philosopher nature can only appear as something found, not according to laws that would be specific to it, but according to the laws of intelligence. These laws, whose origin is to be found in man as a being with a moral destination, and not in some kind of intelligibility proper to nature, allow us to qualify the latter as ideal-real. From the standpoint of the Doctrine of Science from 1794-95, the only that Schelling and Hegel had access to, it would be impossible to solve what Schelling once labelled «the riddle of the world», i.e., the existence of a productive activity that does not originate in the counscious I. The Doctrine of Science is still prisoner of what he also called the "magic circle of self-consciousness», that could be formulated, in fichtean terms, in the following manner: if we abstract from consciousness to speak of a nature outside consciousness, we still presuppose consciousness, since it is her that abstracts ${ }^{12}$.

If we now pay some attention to the critics Hegel addresses to Schelling, we will easily verify that the former is not entirely fair to the latter. One must first remember the main purposes of Schelling's philosophy of nature in its initial form, that is, from 1797 to 1801 . Schelling says that if we want to know what nature really is we must move back from nature as it manifests itself in the natural sciences, to nature as a productive activity. Natural science can at best attain the totalitay of natural phenomena, not nature itself as a selfproductive subject. In other words, Schelling is interested in nature as a self-positing activity, as it could be named in the language inherited from Fichte ${ }^{13}$, i.e., nature as the activity that generates every phenomenon. An activity that precedes the observer at the moment in which he takes it as an object, since any observer, to say it in Schelling's own terms, can only be a potency of that very activity. That's what he says to Fichte in a letter of November $19^{\text {th }} 1800^{14}$. Earlier, in 1797 , in a series of essays published in Friedrich Niethammer's Philosophisches Journal, Schelling had said: "The outer world is there wide open before us» - the German word is aufgeschlagen - «so that we can find in it the history of our own spirit» ${ }^{15}$. Later on, in a polemic against Fichte, in the beginning of 1801, in the essay Über den wahren Begriff der Naturphilosophie, Schelling will say that the I that is an object for the Doctrine of Science shows itself as active and productive since the I that reflects (the philosopher's) takes account of it at the moment in which it is already identical with him. But this identity between the I that observes and the I that is observed was made possible only because the latter became $=\mathrm{I}$; philosophy of nature is the study of the process of constitution of this equality, in other words, of the moments in which the I, struggling to attain consciousness, still produced without being conscious ${ }^{16}$. Now Schelling demands that

\footnotetext{
${ }^{11}$ Fichte, Gesamtausgabe, Stuttgart-Bad Cannstatt, Frommann-Holzboog, 1973, Band III / 4, pp. 359 and ff.

${ }^{12}$ Fichte, WL 1794-95, SW, I, p. 97 / GA, I/2, p. 260.

${ }^{13}$ Schmied-Kowarzik, Ibidem, p. 166.

${ }^{14}$ Full text in Fichte, Gesamtausgabe, Band III / 4, pp. 362 and ff.

${ }^{15}$ Schelling, SW, I, 383 / HKA, I/4, p. 110.

${ }^{16}$ Schelling, SW, IV, p. 86.
} 
in order to gain access to the knowledge of this unconscious productive activity we just retain the "pure objective element» of intellectual intuition, which means that this element should be disconnected from the philosophical subject that makes the intuition, in order that its result might be retained.

As a matter of fact, this unconscious subject, for Schelling, is an objective subject-object; he is a subject-object as long as the distinction between the first and the second, valid only at the level of representation, has no place in nature; he is objective, furthermore, because his self-production is not yet accompanied by consciousness. Some years before, in the Ideas, Schelling had used the expression «invisible spirit» to characterize this situation. The legitimacy of the use of the term spirit lies in the fact that matter, for Schelling, is no more than a certain number of interactions similar to those we experience in ourselves as spiritual beings. In 1799, in the Erster Entwurf eines Systems der Naturphilosophie, after having said that nature possesses an absolute reality, Schelling wrote at the margin of his own exemplar: «nature receives from itself its own reality - is her own product - it is a self-organized whole that continually organizes itself.» ${ }^{17}$

A lot of passages of Hegel, especially in the Encyclopedia, support almost the same ideas. But in them we always find that specific hegelian accent according to which things are never such as they are given to us, and human mind must make some violence upon them so that they are forced to say the truth. As Hegel himself once said, Isis's veil only vanishes in face of thought ${ }^{18}$. In some passages, directed against Schelling's philosophy of nature, above all in paragraphs 246 - 248 of the Encyclopaedia, Hegel criticizes the tendency to grant nature a divine character; to see her as a work of God means only seeing her as the «being-other» of the idea, i.e., as matter sustained by logical structures, and at the same time as a spatiotemporal reality whose being still doesn't correspond to its concept and, for that reason, still contains in its core an unsolved contradiction ${ }^{19}$. Inorganic bodies have figure, but not yet assimilation, as Hegels says in the $\$ 359$ of the Encyclopaedia; they have no needs, what negates them from the outside is not a positive determination of themselves, and they don't carry on their contradictions with themselves ${ }^{20}$. For Hegel, of course, as well as for Schelling, nature is always movement and in it anyone can recognize, in an imperfect form, the most important characteristic of spirit, the unrest; but we can also recognize such a characteristic, says Hegel - and perhaps even more clearly -, in any contingent manifestation of the intelligence, or in a caprice of the imagination ${ }^{21}$. Life itself, in the biological sense of the term, cannot escape, says Hegel, to contingency and caprice, although life is the highest

${ }^{17}$ SW, III, p. 17 / HKA, I/7, p. 276.

${ }^{18}$ Hegel, Encyclopaedia, $\$ 246$ (Glockner, IX, p. 43).

${ }^{19}$ Being and concept are only identical in living organisms. Only they deserve to be called subjects. As Hegel himself says in $\$ 359$ of the Encyclopaedia: «Only a living being feels want; because in nature only he is the concept, the unity of himself and of his determinate opposite. Where there is a barrier, she is a negation only to a third, to an exterior comparision. But the barrier is a want as long as in someone is present, at the same time, the being ahead, the contradiction as such is imanent and is put in it. Such a one that is capable of having in himself a contradiction and of carrying it on is the subject; this constitutes its infinity.» (Glockner, IX, p. 628.)

${ }^{20}$ Idem, Ibidem, $\$ 359$ (Glockner, IX, p. 628).

${ }^{21}$ Idem, Ibidem, $\$ 248$ (Glockner, IX, p. 34). 
product of nature's activity. In individual exteriority and vitality life encounters only other singularities; spiritual works, on the contrary, maintain a free relation with themselves.

I now turn to the problem of existence and of the relation between existences. An existence is something that, as Kant remarked, cannot be mathematically constructed by concepts, but that can only be, instead, the subject of a certain number of principles in order to be known. Kant is perfectly clear about this in the Prolegomena to any Future Metaphysics: we only know phenomena by means of the laws of their connections and will never penetrate so deep in their inner being as to know the particular essence of each one ${ }^{22}$. We know that matter, for Kant, is something that moves itself in space. But a piece of matter doesn't fill space without, at the same time, expelling from it another piece of matter. For Kant, where there is matter there is also some kind of action. And it's force that forbids the same portion of space from being occupied by two different quantities of matter; one repels the other, not because we cannot think of both at the same time at the same place, as Kant had already said in 1763, in the essay on the Negative Magnitudes, since a mere logical contradiction cannot regulate questions of fact, but thanks to the force present in each of those quantities. Thus, force, for Kant, can be an object of investigation in the transcendental part of the Metaphysics of Nature that occupies itself only with concepts that make possible nature in general, whose formal structure is constituted by the four groups of categories of the understanding, established by the Critique of Pure Reason. More precisely, the investigation of the nature of force, once the material content that fills the above mentioned structure is introduced - that is, matter in motion - takes place in dynamics, that deals with bodies in movement as long as they occupy a certain part of space and prevent other bodies from moving into $\mathrm{it}^{23}$.

Attention should be paid to the employment, made by Schelling and Hegel, of the concepts of mechanics and dynamics, an employment that does not exactly correspond to the meaning of these terms in Kant or in our days, as can be easily proved if we open any elementary textbook of physics. Nowadays we don't oppose mechanics and dynamics, instead, the former encloses the latter, as one of its parts (the other being statics), both - statics and dynamics opposed to kinematics (phoronomy, as Kant still calls it in 1786, in the First Metaphysical Principals of Natural Science), since the last studies only the movement of geometrical points in space, regardless of mass. (In mechanics, physics takes into account not the geometrical, but the material point, which we'll define as a quantity of matter that can nevertheless be very small. However, as long as there is matter, in the study of its movement we can't neglect the mass and, in consequence, the action of a force. Dynamics studies the movement of any system of material points, or bodies.) The opposition between mechanics and dynamics, frequent in Schelling and Hegel, constitutes, above all, a counter-position between an attitude regarding nature that admits the possibility of isolating phenomena in relatively independent causal chains, and another attitude that, in von Bertalanffy's language, we could call systemic, that

${ }^{22}$ Kant, Prolegomena, A 111-113: «For we don't know nature but as the totality of phenomena, i.e., of representations within ourselves, and hence we can derive the law of its connections from the principles of their connection in ourselves, i.e., the conditions of the necessary unification in a conscienciosness, wich constitutes the possibility of experience. (...) [The] understanding doesn't derive its own (a priori) laws from nature, it prescribes them instead to it.» Cf. Schmied-Kovarzik, Ibidem, p. 16.

${ }^{23}$ Kant, Metaphysische Anfangsgründe der Naturwissenschaft, Zweites Hauptstück, A 31. 
demands that any totality be analyzed according to the interaction between its constituent parts $^{24}$.

Throughout 1799 and 1800 Schelling elaborated the concept of dynamics that he had inherited from Kant, in its opposition to mechanics. All this work was, with great probability, due to the influence of Karl August Eschenmayer, an author whose influence was almost always present at the fundamental turning-points in Schelling's philosophy ${ }^{25}$. As mechanicism, also called atomism, tells us what we could know about nature if it was the physicist who produced it, dynamics tells us how nature itself operates; so, dynamic's relation to physics is the same as the relation of transcendental philosophy to the philosophy that has anteceded it:

"The dynamical is for physics exactly the same as the transcendental is for philosophy, and to explain dynamically means is physics exactly the same as to explain trancendentally means for philosophy. That a phanomenon is dynamically explained means that it will be explained precisely from the originary conditions of the construction of matter.» ${ }^{26}$

This comparison however, enlarges the scope of transcendental philosophy in such a way that it anticipates its overcome, as it will eventually happen in 1801. Until then, Schelling can only go on defending the transcendental character of his explanation as long as he says that all dynamic movements have their last foundation in the subject; but since, from now on, such a subject is nature, all his explanation still retains a language- inherited from Fichte - in which it doesn't feel itself very confortable.

Having clarified this issue, we still must underlie the fact that Schelling will retain from the Kantian notion of force a fundamental idea: force is basically a power of attraction and a power to repel, and, besides serving to explain why a certain portion of matter expels another portion from the same space - the classical Cartesian notion of impenetrability would also serve this purpose - it explains its subsistence in this same space, or the effort to stay there. In 1800, in a small but very important essay named Allgemeine Deduktion der dynamischen Prozesse, published in a magazine founded that same year (the Zeitschrift für spekulative Physik), Schelling will explain all this with enough clarity. If filled space - he says - that resists invasion (that is to say, repels) must be regarded as possessing a certain degree or intensity of force, then, to such a degree will also correspond the kind of cohesion its parts manifest. But to this idea of Kantian origin Schelling will join another that we won't find in Kant: matter - Schelling goes on - possesses a spiritual nature that manifests itself in the reciprocal behavior of its constituent forces in their relation to space $^{27}$; only it is a level of

${ }^{24}$ Ludwig von Bertalanffy, General System Theory, New York, Georg Braziller, 1968, p. 55. Obviously, the relation between a whole and its parts acquires, in the general system theory, a complexity that is absent in the philosophy of German Idealism. The reason for this lies, probably, in the mathematical model choosen to explain that relation, i.e., the non-linear differential equations, too much sophisticated for the mathematical knowledge available at the beginning of nineteenth century. Anyway, the distinction between von Bertalanffy's systematic and analytical procedures - this last one applicable to situations where the relation between parts is negligeble (cfr. General System Theory, p. 19) - was clearly formulated by Schelling and Hegel.

${ }^{25}$ The strong and permanent influence of Eschenmayer on the evolution of Schelling's philosophy - to whom Schelling even borrowed some of his most fundamental concepts of philosophy of nature, like the concept of potency - had already benn noted by the contemporaries. See, for exemple, Johann Eduard Erdmann, Versuch einer wissenschaftlichen Darstellung der Geschichte der neueren Philosophie, Leipzig, 1834-1853, Band 6/II, pp. 276 and ff.

${ }^{26}$ Cf. Schelling, Allgemeine Deduktion des dynamischen Prozesses, $\$ 63$, SW, IV, pp. 75-76 / HKA, I/7, p. 364.

${ }^{27}$ Allgemeine Deduktion, $\$ \$ 30$ e 31. 
spiritual activity that contemplates itself in a state of equilibrium. That's a transitional state, anyway, because matter possesses an active potency that pushes her towards the dynamical process of the magnetic, electric and chemical phenomena, and, from this, to the organic process of progressive individuation ${ }^{28}$.

In his appraisal of the Kantian concept of matter, in the Science of Logic and in the Encyclopedia, Hegel is deeply indebted to these ideas of Schelling ${ }^{29}$. Hegel underlies the moment of singularization, or individuation, that corresponds to the repulsive force and the moment of continuity, that corresponds to the attractive force, ideas that were already present in Kant and without which Kant's own critic of impenetrability would remain unintelligible. But, although Hegel was willing to recognize that in Kant matter had been for the first time raised to the level of concept (as its determinations no longer belonged exclusively to the realm of experience ${ }^{30}$ ), he nevertheless criticizes Kant for having taken those two forces as reflexive, that is to say, rigid determinations: in his characteristic reflexive way of thinking, says Hegel, Kant sees the action of those two forces first as empirical determinations of phenomena, since his point of departure is the perception of those determinations, then puts them as foundations of the phenomena, and finally in order to explain them acknowledges the action of fundamental forces that are supposed to produce those determinations. Kant's procedure is for Hegel essentially an analytical one, and not systematic (or constructive, as Kant calls it). Of course, what Hegel criticizes in Kant is a «metaphysical explanation» - I put it between quotation marks since it is not really metaphysical from Hegel's standpoint - to strongly tied with the empirical concepts of science.

\section{Living Beings}

In an organic totality, cause and effect are not entirely separable. It doesn't make any sense to speak of a part as the cause of an effect in another part. All the parts are interrelated and we can say that each of them affects the totality, and is affected by it. Every organic unity is governed by a concept that determines what the interaction between the parts and the interaction of the whole with its environment will be. (Very much like what von Bertalanffy has called «open systems».) Schelling will say that the organism in not just a form of individuation of matter like any other form, but precisely that form in which the effects don't loose themselves outside the organism but, reverting to it, give him a power and autonomy that any other product of nature doesn't have. The organism, Schelling will say in 1798, in Von der Weltseele, is a succession of causes and effects interrupted in its linear movement and, for that reason, permanently returning to itself ${ }^{1}$. The organism is also an analogon of freedom, since it is not only pure affirmation of itself (what the inorganic world already is), but a determination of that affirmation in particular directions. Perhaps, in the general system

\footnotetext{
${ }^{28}$ Schmied-Kowarzik, Ibidem, p. 167.

${ }^{29}$ Cf. Encyclopaedia, $\$ 262$ (Glockner, IX, pp. 93-97).

${ }^{30}$ Hegel, Wissenschaft der Logik, in Werke, Band 5, Frankfurt am Main, Suhrkamp, 1986, pp. 201-202.

${ }^{31}$ Schelling, SW, II, pp. 348-349 / HKA, I/6, p. 69.
} 
theorie's language, we could express this last characteristic as the constitutive aspect of organisms $^{32}$. This means that we don't take in consideration only the number of parts of a whole, or the different species they belong to, but above all the kind of relations that obtain between them. We could then give the expression «the whole is more than the sum of parts» an explanation other than mystical, since it would mean that the characteristics of an organism are not explanable from the characteristics of isolated parts.

We can find similar assertions in Hegel. In the Addendum to $\$ 344$ of the Encyclopedia he says that organic beings possess internal differences, they are a unity in a multiplicity. But in animal organism we find a more accentuated difference than in plants between the substantial form and each one's particularity; that's why an animal has sensations. In other kinds of bodies, in crystals, for example, the process of individuation is much less developed. As a non living body, a crystal stays closed before the other crystals, his particular determination is independent of any influence coming from outside (it's a «closed system», in von Bertalanffy's language) and the surface of his body, Hegel says, is limited by the form ${ }^{33}$. His individuality is not yet objective for itself, so that we should speak hear, more appropriately, in spite of the inner articulation of the constituent parts, of an absence of soul. In an organic body, on the contrary, the figure is already a subjective form and each of its parts is a manifestation of the whole. One could easily show that this assumption stems from Schelling and his interpretation of the meaning of individuation, as an essential element of the evolutionary process. Every individuation requires, for him, a particular principle that explains it, that is, individuation is not entirely deductible of the mere mechanism of causes and effects. Schelling had said in 1799:

«Since nature as an absolute productivity must be authentically thought as comprehended in an infinite evolution, the stability, the quietness of nature's products (of organic products, for instance) should not be represented as an absolute rest, but as an evolution with an infinitely slow acceleration, or with an absolute belatedness. ${ }^{34}$

Living systems are then unities of interaction. Schelling says, in 1799, in the Einleitung zum Entwurf that they exist a priori; just in the same way, our knowledge of them is also a priori, which means that, even if it begins with empirical observation, it expresses nevertheless the inner necessity peculiar to the thing known ${ }^{35}$. Such an a priori character of living systems manifests itself in the fact that its parts have their origin in the whole, and not the other way round, and that each individual, in his singularity, is determined by the idea - what we would today perhaps call the internal structure - characteristic of the nature of the system to which it belongs. (We had to speak hier of the strong influence of Kielmeyr and Blumenbach on Schelling's philosophy of nature ${ }^{36}$.) With an infinitely grater complexity than in non

\footnotetext{
${ }^{32}$ Ludwig von Bertalanffy, op. cit., pp. 54-55.

${ }^{33}$ Hegel, Enciclopédia, $\$ 310$, Zusatz (Glockner, IX, p. 268): «So, also the surface of the body is limited by the form; the body is closed in face of others and shows its specific determination in its quiet stability, without acting upon the outside."

${ }^{34}$ Schelling, SW, III, p. 287 / HKA, I/8, p. 43.

${ }^{35}$ Schelling, SW, III, p. 279 / HKA, I/8, p. 36.

${ }^{36}$ From K. F. Kielmeyer (1765-1844) we should mention the lecture of 1793 intitled «On the relations of organic forces", where he proposes an hierarchy of three fundamental forces of animal life, sensibility, irritability and
} 
living systems, life is nevertheless the result of the combinations of pre-existing elements, though life if above all an open system, in which the metabolism of living beings manifests itself in an indefinite number of exchanges between their own constitutive matter and the environment ${ }^{37}$. This means that life has always to face an unlimited number of situations that could hardly have been foreseen. But this recurrent opportunity of new inventions, proper of a system organized according to what Von Neumann called the "self-restoring tendency» is visible in man in a super-accelerated rhythm, of which we cannot guarantee that an algorithm exists that would be able to express it.

For a living system, the environment that surrounds those interactions that allow the restoration of the organism is, in Humberto Maturana's terminology, its niche ${ }^{38}$. Inside it, life has a circular character. It exists to realize the conditions that allow it to sustain itself. For Schelling, the whole nature- and not only living systems - contributes to the reproduction of its particular products in such a way that we only see that constant productivity, and never nature at rest ${ }^{39}$. However, the fundamental opposition seems to be, for Schelling, not the one that exists between the inorganic and the organic, but that which exists between the first two potencies of nature (the first where predominates an antithesis between light and weight, the second characterized by the phenomena of electricity, magnetism and chemistry) and the third potency that begins with the appearance of man, consciousness and freedom ${ }^{40}$. Frequently, organic and inorganic bodies, in Schelling, receive the same kind of explanation, in terms of its structural properties and functional relations ${ }^{41}$.

We can find the following definition of life, in Von der Weltseele: «The ground of life is contained in opposite principles; one of them (the positive) has to be looked for outside the individuals, the other (the negative) in the individual himself.» ${ }^{42}$ The equilibrium between the functionning of the two mentioned principles keeps the organism in life, so that this equilibrium could be called homeostatic. Schelling's position seems to be very close to the one of Maturana and Varela: like them, he says that all living systems are characterized by a certain kind of relations between its components that are very diferent from the kind of relations present in non-living beings, since those components have themselves a relational character. Therefore, we can reasonably postulate the existence of an organization that is commom to all living beings - they are all relations of relations, although the particular way

reproduction, that largely influenced Schelling's view on those matters. (Cfr., for exemple, the above-mentioned essay of 1799, "General deduction of the dynamical process».) J. F. Blumenbach (1752-1840) was the creator of the concept of Bildungstrieb (formative instinct), that intended to prove that in the development of animal life systemic factors played a more important role than mere mechanical ones.

${ }^{37}$ About life as an open system, cf. von Bertalanffy, op. cit., p. 55.

${ }^{38}$ Humberto Maturana, in Humberto Maturana and Artur Varela, Autopoiesis and Cognition, Dordrecht $/$ Boston, London, D. Reidel Publishing Company, p. 9.

${ }^{39}$ Schelling, SW, III, p. 18 / HKA, I/7, p. 83: «Nature is absolutly active, since in each of its products lays an explicit development».

${ }^{40}$ Schmied-Kowarzik, Ibidem, p. 116.

${ }^{41}$ Esposito, op. cit., p. 99.

${ }^{42}$ SW, II, p. 503 / HKA, I/6, p. 192. 
in which they are carried may be different for each of them -, regardless of the class the organism may belong to ${ }^{43}$.

Let us now imagine the following situation: in two different moments of time, $T_{1}$ e $T_{2}$, the same organism $\mathrm{O}$ has two different appearences. (We suppose it was subjected to a transformation in result of the joint action of those two principles we mentioned earlier.) Our problem is to know how to guarentee the identity of this organism, that means, the possibility for us to recognize it as being always the same. Maturana and Varela speak of a contínuos system of disorders and of compensation of these disorders. A living organism is described as a homeostatic machine (or as a static relational system) whose organization constitutes the only variable he has to keep constant ${ }^{44}$. In this respect, Schelling speaks, concerning an individual body, of the existence of two kinds of equilibrium: the general equilibrium of the forces that constitute matter and his own determinate equilibrium. This second equilibrium, resulting from a synthesis between the first equilibrium and an «alien principle» that troubles it and awakenes the life-force that was inactive in it, gives to every natural body not only the occasional character of his organization, but also the peculiarity of his figure ${ }^{45}$. So, in an individual product is allways visible the productivity that has constituted it, although provisionally refrained. But the fact that a body is fixed in his individuality doesn't mean that the general equilibrium of the forces can be indefinitly maintained. The opposition between the forces only acquired, for Schelling, new forms, and perhaps we could say that it has modalized itself (in the sense that Spinoza spoke of the finite modes of substance), manifesting itself in the continuous reproduction of the product.

\section{Self-Organization}

It's possible to make a list of the characteristics that allow us to call a being a «living being»: reproduction, heredity, growth, sensibility, etc. But what is the real extension of this list? To answer this question, we should, at first, be capable of answering the questions: "what's a living being?»; "what's the specific feature of all living beings, that differentiates them from the non-living? ${ }^{46}$ Although Schelling grants some specificity to living beings, one of his concerns, for exemple in Von der Weltseele, from 1798, is to show the existence of a continuity between the living - the organic - and the non living - the inorganic -, since

\footnotetext{
${ }^{43}$ Maturana e Varela, in Maturana and Varela, Autopoiesis and Cognition, ed. cit., p. 76. The authors recognize thar this mode of thinking is not new, but stangely they call it "mechanicism». That's the very word Shelling's philosophy of the organism tries to avoid. Nevertheless, their definition of a "living machine» fits Schelling's definition of organism: "There are machines which maintain constant, or within a limited range of values, some of their variables. The way this is expressed in the organization of these machines must be such as to define the process as occurring completely within the boundaries of the machine which the very same organization specifies. Such machines are homeostatic machines and all feed-back is internal to them.» (p. 78)

${ }^{44}$ Idem, Ibidem, p. 79.

${ }^{45}$ Francesco Moiso, «Geometrische Notwendigkeit, Naturgesetz und Wirklichkeit. Ein Weg zur Freiheitsschrift», in H.-M. Baumgartner und Wilhelm Jacobs (Hrsg.), Schellings Weg zur Freiheitsschrift, Legende und Wirklichkeit, pp. 132-186, pp. 142 and ff.

${ }^{46}$ Maturana, in Ibidem, p. XIII,
} 
both manifest the existence of a polarity between two forces of opposite direction ${ }^{47}$. Besides, it's this identity of processes, in the organic and the inorganic world, that gives its legitimacy to a kind of foundation of nature that Schelling, until the end of the 18th century, still labels transcendental: in both worlds we notice the action of the forces of expansion and attraction, and that's what allows us to construct both of them from our faculty of intuition, where they also take place.

Maturana says that what is unique in the adaptation process of living beings - what makes them a structurally plastic unity - is the fact that in all of them the auto-poietical organization constitutes an invariant configuration of relations around which the selection of structural changes takes place, in the course of the history of the interactions with the environment ${ }^{48}$. As long as we can speak about auto-poiesis in Schelling, it constitutes for him a permanent characteristic of all natural phenomena; it allows us to construct them immanently, without the help of a transcendental explanation of the fichtean kind. And in the General Deduction of the Dynamical Process, the independence of philosophy of nature from transcendental philosophy is oppenly proclaimed. In the language Schelling inherited from Fichte, auto-poiesis is labelled «subjectivity». That's why theoretical philosophy can speak of an I that produces in nature, in the same sense that practical philosophy speaks of an I that produces in history.

And so I come near to the last part of this paper, in which I intend to analyse the relevance of the notion of system in the fields of history and freedom. Schelling and Hegel's positions about this question are somewhat different, and Schelling's early conceptions are sometimes alien to what one might call the common sensibility of the main representatives of his generation. (Above all in his doctrine of the state.) They show nevertheless remarkable coherence along the philosopher's whole work, perhaps with the sole exception of the Lectures on the Method of Academic Studies from 1803. In these lectures, Schelling develops indeed an organic theory of the state, but in deep contrast with previous assumptions according to which the state is only an artificial mechanism and only society could be organically organized. As an exemple of those early conceptions, we could mention the brief and unfinished text published in 1796 named New Deduction of Natural Law, written a bit hastily as Schelling wanted to anticipate Fichte's book about the same theme, annouced for the following year. Albeit its circumstantial character, it must retain our attention since it is the only text of Schelling exlusively dedicated to the realm of practical philosophy; it has also the merit of clarifying the theological-political pathos that emerges in certain of his books, published earlyer or shortly after.

Schelling's philosophy of nature and Schelling's practical philosophy were always interconnected $^{49}$. How the world really is and how it should be for a moral being are not two entirely different questions from the standpoint of the spinozistic monism that pervades

\footnotetext{
${ }^{47}$ SW, II, pp. 350 and 569 / HKA, I/6, pp. 70 and 257. Schmied-Kowarzik, Ibidem, pp. 113-114.

${ }^{48}$ Maturana, in Ibidem, p. XXI.

49 There are not many studies available about Schelling's practical philosophy and its connections with his general philosophy. The book from Allexander Hollerbach, Der Rechtsgedanke bei Schelling, Frankfurt am Main, V. Klostermann, 1957, is still indispensable. More recently, cfr. Marc Maesschalck, L'Anthropologie Politique et Réligieuse de Schelling, Paris /Leuwen, J. Vrin / Éditions Peters, 1991.
} 
Schelling's early writtings; but only in so far, at least it seems to me, as this spinozism is (as we might say) corrected by a leibnizian standpoint: which means that the necessary world order has an ultimate moral ground. In the above-mentioned Deduction, Schelling argues that nature's power vanishes in front of the original power of the I as a moral reality, and, on the other side, that the I's activity (that means, my own activity as long as I am not only nature) only vanishes in front of the activity of other Is. Schelling tries to elaborate a theory of the ideal world, or a theory of freedom, in which she will be defined neither negatively only, as something which escapes determinism, nor in an indeterminate manner, as something of which no reason can be given. But to understand freedom - as philosophy of nature had done for natural phenomena - from the concept of self-organization means to go beyond the level of the individual to the level of the species. The human species is the real acting subject in history. Only for the species, action and the intuition of the results of action coincide. Where no identity between both obtains there is no freedom, only blind necessity.

But the claims, by another rational being, to a certain portion of space are if I also intend to occupy it an obstacle to my own activity. The activity of other rational beings, directed to the same objects my will directs itself to, transforms those rational beings in limits to my own activity. The counsciousness of a limit is therefore the result of reciprocalaction between the different intelligent beings that constitute humanity as a species: the activity of an intelligent being directed towards an object forces another inteligence to go back to itself, as it recognizes the presence of an obstacle. Without other intelligences there would of course be no obstacles, but in such case the will would be blind and undistinguishable from a natural impulse; the individual, in such conditions, would not be, in fact, an intelligence. The juridical law and the state are necessary as long as they regulate the relations between conflicting wills. But they are not destined to subsist for ever. The community of the inteligent beings must learn to organize itself by reciprocal-action between its members. What Schelling calls the universal juridical constitution (allgemeine Rechtsverfassung), that human history shall produce, will give itself its own order. 